\title{
NEW INDUSTRIAL POLICY IN CENTRAL AND EASTERN EUROPE: DEVELOPMENT'S EXPERIENCE AND CONCLUSIONS FOR UKRAINE
}

\author{
НОВА ПРОМИСЛОВА ПОЛТТИКА В КРАЇНАХ \\ ЦЕНТРАЛЬНОЇ ТА СХІДНОЇ ЄВРОПИ: \\ ДОСВІД РОЗВИТКУ ТА ВИСНОВКИ ДЛЯ УКРАЇНИ
}

\section{Tetiana Obelets ${ }^{1}$}

DOI: https://doi.org/10.30525/978-9934-588-15-0-40

\begin{abstract}
In this division of monograph experience of the new going is analysed near industrial politics of successful countries of region of Central and East Europe (CEE). Research method. The method of comparative analysis of new industrial politician is used for research of similar with Ukraine economies of Poland, Chech Republic and Hungary. By the method of ascent from part to general we defined such general and distinctive signs politician of countries of region of CEE. Main part. We are studied, analyzed and groupped an instruments of industrial politics in area of stimulation of Export, including for the enterprises of small and middle businesses (SME). These mechanisms were worked out and successfully mastered in the United States of America and were used on the stages of economic transformation of post-socialistic countries. We distinguished the features of vertical and horizontal instruments of industrial politics and then the most often applied events of Hard and Soft variants of industrial politics are structured in a CEE region. In this Region it was come forward basis of successful stimulation of height of industry such as presence of own currency (zloty, chech crowne and forint) and realization of independent currency-course politics, creation of industrial parks and special economic zones, and also application of mechanisms of reduction of prices and insurance of export by means of Export-credit Agencies. By the distinctive feature of Poland in realization of industrial politics there is reducing of
\end{abstract}

\footnotetext{
${ }^{1}$ Candidate of Economic Sciences, Senior Lecturer,

National Technical University of Ukraine

«Igor Sikorsky Kyiv Polytechnic Institute», Ukraine
} 
greater part and successful restructuring of remaining volume of a Sovereign debt on new basis. This Debt was re-profiled on the advantageous terms for Poland both before international financial organizations (IMF, World bank etc.) and before large private creditors. Reduction of promissory burden pawned basis for creation of new workplaces and technological rearmament in industry, that resulted in the speed-up economy growing of Poland. The feature of new industrial politics of Hungary are state measures on support of enterprises with specialization on NT with the large stake of value-added - in particular electronics. It distinguishes Hungary from nearby Republic of Slovakia, where by a government a course was taken on stimulation of creation of cluster of automobile and motor industry. Also the feature of Hungary is the developed system of trade houses with the purpose of advancement of the Hungarian export abroad at the financial assistance of the state participating Export-import bank and Export-credit agency, working in close cooperation. Conclusions. We recommend within the framework of realization of new industrial politics in Ukraine actively to bring over small and middle enterprises (SME) to export activity. We proposed for stimulation industrial policy as important institutional mechanism to establish the specialized state Agency of development of small and midsize businesses in Ukraine. It can become for example of the United States of America, with the use of real experience of countries of region of CEE. Using experience of Hungary, we offer creation by Government the National Trade House in Ukraine for financial and organizational support of advancement of export in co-operating with state specialized Ukreximbank and accrued Export-credit Agency of Ukraine. Also we consider a necessity to used Poland's and Chech Republic's experience on creation of the ramified network of Industrial parks on all territory of the country in Ukraine.

\section{1. Ветуп}

Відтворення капіталу в умовах переходу до економіки знань в рамках підходів «Промисловості 4.0» передбачає забезпечення структурних економічних зрушень на власній продуктивній основі. Це неможливо забезпечити без реалізації державної промислової політики.

На міжнародній арені багато науковців досліджували зміни у промисловій політиці розвинутих країн та країн, що трансформуються. Зокрема, Е. Райнерт [14, с. 205] пише: «країна без промисловості й 
далі повинна коритися залізним законам зменшуваної прибутковості. Навіть якщо технологічні зміни можуть посунути гнучкий мур, він стоїть і далі». В своій доповіді до 50-річчя Римського клубу фон Вайцзеккер та Війкман наголошують, що «увесь наш промисловий сектор нині здійснює цікавий перехід до «Промисловості 4.0»... у зв'язку із відновлювальними джерелами енергії» [1, с. 182]. Без розвитку нової екологічно орієнтованої промисловості неможливо «ефективне управління обмеженими ресурсами для досягнення найкращого результату в інтересах більшості людей з належною повагою до природи»- пише Г. Макстон [9, с. 283].

Держава визначає критерії регулювання економіки з метою встановлення балансу між інтересами бізнесу та потребами соціальноекономічного розвитку країни, і саме це, за висновком В. Панченко та Н. Резнікової, дає змогу «віднайти раціональну структуру внутрішнього господарства і використати потенціал науково-дослідних та дослідно-конструкторських робіт (НДДКР). Таким чином досягається реалізація завдань постійного осучаснення економіки, ії̈ сталого зростання, що неодмінно сприятиме підтриманню належного рівня національної безпеки» [13, с. 96-97].

Промислова політика є базовим компонентом загальнодержавної економічної політики, спрямованої на досягнення мети прискореного зростання та сталого розвитку. Ефективні інвестиційна й фінансова політика заохочуватимуть високо технологічний імпорт та направлення наявних ресурсів для розвитку пріоритетних секторів промисловості.

Але необхідне закріплення чітких правил співіснування бізнесу і держави, встановлення системи покарань за корупцію та недобросовісність бізнес-поведінки. Одночасно з цим застосування системи стимулів за інноваційність бізнесу та його соціальне спрямування дозволить провести нову індустріалізацію країни.

Мета дослідження - аналіз нових підходів до промислової політики у країнах регіону Центральної та Східної Європи, що досягли значних успіхів у пост-соціалістичній трансформації на шляху по приєднання до Європейського Союзу шляхом компаративного аналізу власних та запозичених у більш розвинутих країн, зокрема, США заходів щодо стимулювання переходу економіки цих країн на шлях розвитку. Це дозволяє науці і високотехнологічним секторам про- 
мисловості стати локомотивом економічного зростання, забезпечити адекватні умови для розвитку малого та середнього бізнесу та виробничого сектора економіки нових технологічних укладів. Матеріалами для дослідження є звіти Міжнародних організацій OECD, UNCTAD, Агентств розвитку малого та середнього бізнесу та Експортно-кредитних агенцій відповідних країн.

\section{2. Теоретичні основи трансформації промислової політики}

Під «промисловою політикою» експерти UNCTAD [28] пропонують розуміти «будь-який вид цілеспрямованих заходів або державної політики, який покликаний переорієнтувати галузеву структуру виробництва на ті сектори, які, як прогнозується, зможуть відкрити ширші перспективи для економічного зростання, ніж в разі відсутності таких». Такі заходи спрямовуються на диверсифікацію внутрішньої структури виробництва і сприяння накопичення потенціалу в нових галузях економіки або в нових видах діяльності, і $є$ частиною так званої вертикальної промислової політики.

Українські дослідники достатньо глибоко опрацювали трансформаційні зміни в галузі нової промислової політики. Зокрема, В. Галасюк [2, с. 49], I. Гужва [3, с. 84-85] досліджують стимулювання експорту і тарифний протекціонізм у зовнішній торгівлі та механізм розвитку промисловості через індустріальні парки. В. Корнєєв [8, с. 180-181] вивчає вплив на промисловість фінансових посередників та державну фінансову політику розвитку. В. Панченко [13, с. 10-20] та Н. Резнікова $[15$, с. $48-51 ; 16$, с. $7-10]$ в своїх працях розробили теоретичні засади переходу від неопротекціонізму до наступної стадії - економічного націоналізму. Зокрема, вони підкреслюють, що «поняття «промислова політика», «галузева політика», «секторальна політика», «індустріальна політика» в вітчизняній практиці та теорії вважаються як синонімічні, хоча у зарубіжній літературі термін «індустрія» означає будь яку область виробничої діяльності, в тому числі і сферу послуг» $[12$, с. 5]. Але якщо цей термін означає «галузь», то він використовується у вузькому розумінні і відображає саме галузеву політику.

На сучасному етапі існує застарілий вже розширений консенсус, що промислова політика повинна забезпечити конкурентоспроможність всього сектора виробництва і передбачає охоплення практично 
усієї частки економічних галузей, що продукують внутрішній валовий продукт. При такому підході, «окрім саме промислових галузей, пропонується також стимулювання будівництва, транспорту, сільського господарства і сфери послуг» [17, с. 6].

Але такий розширений підхід, на нашу думку, не сприяє вирішенню питання щодо осучаснення «місії України» не як аграрної, а нової індустріальної держави. Досвід багатьох країн, що розвиваються, засвідчує, що модернізація, що віддана на відкуп вільному ринку, без проведення заходів проактивної промислової політики, не здатна вирішити завдань структурної трансформації економіки в цілому. Втім, на нашу думку, промислова політика не має обмежуватись вирішенням проблем окремих галузей, а сприяти підвищенню ефективності економіки шляхом оптимізації розподілу ресурсів та адекватного реагування на зовнішні шоки.

О. Москаленко [10, с. 462] підкреслює, що «міжнародна технологічна нерівномірність визначає диференціацію країн за рівнем економічного розвитку. У розвинутих країнах активно формується новий технологічний спосіб виробництва, який ... містить такі технології, як біотехнології, системи штучного інтелекту, глобальні інформаційні мережі та інтегровані високошвидкісні транспортні системи, нанотехнології тощо». Саме вони визначають місце країни у майбутньому глобальному розподілі.

Роль Уряду у розробці промислової політики насамперед полягає у створенні інституційного середовища, яке б уможливило впровадження дієвих заходів задля забезпечення прогресивних змін в структурі промислового виробництва шляхом залучення додаткових і перерозподілу наявних ресурсів. Такий підхід передбачає розгляд нової промислової політики як сукупності певних заходів, що описані у відповідній програмі дій згідно обраній стратегії залежно від сформульованих цілей. Ефективна промислова політика реалізується як загальнодержавними, так і місцевими органами влади через розробку і впровадження певного комплексу заходів із підвищення конкурентоспроможності промислового комплексу задля забезпечення економічного зростання в країні. Перехід до вищих технологічних укладів як запорука підвищення соціально-економічних стандартів в країні можливий лише у випадку комплексної структурно-технологічної перебудови застарілої промисловості. 
Дослідники загалом виділяють дві моделі промислової політики жорстку та м'яку [12, с. 6-7]:

1) Жорстка модель передбачає використання такого інструментарію, як:

- прямий перерозподіл ресурсів країни на користь конкретних суб'єктів господарювання або галузей;

- пільгове оподаткування, субсидування;

- наявність державних замовлень;

- пряме інвестування;

- державне регулювання цін на окремі категорії товарів;

- державні гарантії за позиками суб'єктів;

- наявність високого мита на товари неінвестиційного і несировинного характеру;

- асиметричність інформації;

- високий рівень присвоєння бюрократичної ренти.

Ця модель спирається на субсидування з бюджету та пільгове кредитування підприємств пріоритетних галузей. Але це передбачає реалізацію протекціоністського курсу у зовнішній торгівлі, спрямованого на створення так званих «тепличних» умов для національних виробників $\mathrm{i}$ залучення прямих іноземних інвестицій, які мотивуються зацікавленістю в уникненні високих вхідних тарифів для готових товарів при імпорті.

2) М'яка модель передбачає використання іншого інструментарію, a саме:

- підтримка конкурентоспроможності національних компаній і ведення бізнесу у всіх галузях без виділення суб'єктів державної підтримки;

- технічне регулювання;

- страхування ризиків виробничої діяльності та нефінансова підтримка експортерів;

- допомога у проведенні R\&D;

- розвиток інфраструктури;

- навчання і перекваліфікація персоналу;

- висока «якість» бюрократії та низькій рівень присвоєння бюрократичної ренти.

Це дозволяє робити акцент на сприянні зростання конкурентоспроможності національних виробників, вирощуванні так званих «національних чемпіонів» при підтримці державними агенціями та міністер- 
ствами інвестиційних інфраструктурних та інноваційних проектів, які дозволяють приватному бізнесу в країні підвищити рівень ефективності.

Таким чином, промислова політика може концентруватись на створенні і розвитку пріоритетних галузей економіки, а також орієнтуватись на стимулювання діяльності національних компаній-виробників. Наразі, яким би не був досвід розвинених країн у використанні потенціалу промислових галузей економіки та інструментарію реалізації промислової політики треба враховувати стадійність розвитку економіки та стратегічні задачі, які стоять перед державою. На етапі реалізації політики нової індустріалізації вкрай важливе запозичення технологій та інвестиційний імпорт, що стимулюються низькими митними тарифами, податковими пільгами, субсидіями споживачам інвестиційного імпорту та обмеженням імпорту готової промислової продукції. В контексті переорієнтації на виробництво високотехнологічної продукції інвестиційний імпорт (машини, обладнання, устаткування) може мати значно більший позитивний ефект для економіки, ніж позитивне сальдо торговельного балансу. Для країн перехідного типу імпорт технологій, іноземні інвестиції та ліцензійна діяльність часто відіграють важливішу роль, ніж виробництво з використанням застарілих, або недостатньо ефективних вітчизняних технологій. Зменшення платіжних дисбалансів, що ставиться за мету політикою Міжнародного валютного фонду, в такому випадку не виглядає як самоціль, адже негативний торговельний баланс, який вочевидь виникне у разі оплати дорогого імпорту, в такому випадку не є результатом «проїдання» кредитних ліній, а реалізації державницької економічної політики, націленої на подальше економічне зростання.

На наступному етапі експортно-оріснтованого зростання вживаються інституційні, адміністративні і валютно-монетарні інструменти стимулювання експорту. Збільшення експорту промислової продукції як елемент вирішення проблеми передбачає низку взаємопов'язаних задач, які повинні виконуватися комплексно, сінергетично підвищуючи ефективність кожного 3 них. Монетарний режим гнучкого таргетування інфляції або вибір жорсткого обмінного курсу сприятиме залученню прямих іноземних інвестицій у пріоритетні галузі економки. Використання ринкових механізмів державного стимулювання промислового експорту з великою часткою доданої вартості призведе 
до підвищення конкурентоспроможності власної промислової продукції, а здійснення дієвих програм імпортозаміщення підтримає валютний курс національної грошової одиниці.

На етапі прискореного розвитку економіки можливе зниження прямого впливу держави на великий бізнес та надання пріоритету підтримці малого та середнього бізнесу. Допускається зниження тарифних та/або нетарифних бар'єрів у експортно-імпортній діяльності у взаємодії із заходами оптимізації податкової та митної політики, в першу чергу, з метою заохочення притоку довгострокових неспекулятивних прямих іноземних інвестицій. Стимулюється географічна диверсифікація зовнішньоторговель-них потоків задля використання країною потенціалу нових швидкозростаючих ринків. Логічним стає державне стимулювання зростання заробітної плати та підвищення освітнього рівня робочої сили.

На етапі сталого розвитку ринку горизонтальні інструменти промислової політики виходять на перший план, а вертикальні інструменти використовуються у контексті контр-циклічної політики. Завчасне застосування горизонтальних підходів може виявитися неефективним наприкінці фази зростання.

Таким чином, ефективність реалізації нової промислової політики визначається оптимальним поєднанням загальних (заходи забезпечення рівних умов конкуренції для всіх галузей і суб'єктів підприємницької діяльності) і селективних (заходи підтримки окремих пріоритетних галузей і суб'єктів підприємницької діяльності, зокрема МСБ) інструментів державної підтримки. Особливо ефективні дії можуть бути у сфері державно-приватного партнерства (цільові програми, інвестиційні та інноваційні проекти, угоди про розподіл продукції, спільні підприємства, регіональні інвестиційні та інноваційні проекти, велика приватизація, вертикальне інтегрування, злиття та поглинання компаній задля формування промислових національних чемпіонів).

При розробці нової національної промислової політики треба враховувати як економічні так і геополітичні чинники. Як резюмує Г. Кіссінджер: «політична та економічна організації світу суперечать одна одній. Міжнародна економічна система стала глобальною ,тоді як політична структура світу і далі будується на національних державах. Економічна глобалізація за своєю суттю ігнорує національні кордони» [5, с. 294-295]. 


\section{3. Досвід стимулювання промислової політики США, який використовували країни регіону ЦСЄ}

У промисловій політиці розвинутих країн підкреслюється важливість нематеріальних факторів (інформації, наукових знань, кваліфікації робочої сили) у забезпеченні конкурентоздатності підприємств. Країни Центральної та Східної Свропи (ЦСЄ) поряд із досвідом Свропейського Союзу використовували й багаторічні напрацювання світового лідера - США.

США послідовно проводять промислову політику 3 метою підтримки життєздатності своєї промислової бази і забезпечення свого глобального технологічного лідерства. В останні роки увагу директивних органів Сполучених Штатів не було зосереджено на забезпеченні розробки національних стратегій і національних програм централізованими координаційними установами в інтересах розвитку конкретних галузей, незважаючи на те, що така модель періодично використовувалася в минулому. Замість цього вони використовували більш децентралізований підхід, при якому в рамках цілого ряду ініціатив і програм, розроблених на федеральному рівні та на рівні штатів, виявлялася підтримка як традиційним, так і новим стратегічним галузям.

Непрямі заходи «м'якої» промислової політики здійснюються в рамках розробки інноваційних програм, зокрема, це:

MEP (Manufacturing Extension Partnership - США) - призначена для забезпечення відповідності малих виробничих фірм міжнародним стандартам якості й ефективності;

$\boldsymbol{A T P}$ (Advanced Technology Program - США) - виплачуються субсидії на розробку і комерціалізацію базових технологій;

Програми $\boldsymbol{C R} \boldsymbol{A D} \boldsymbol{A}$ (Cooperative research and development agreementsСША) i SBTTP (Small business technology transfer program - США) [30] дозволяють вченим та інженерам федеральних лабораторій співпрацювати з колегами із зовнішніх організацій в області розробки і комерціалізації нових технологій шляхом спільного фінансування державою наукових досліджень, що замовляються фірмами в НДІ і ВНЗ. Відзначається, що дана схема проста в управлінні, має швидку віддачу, але більше відповідає діючим підприємствам, що вже займаються НДДКР. Аналогічні програми діють і на міжнародному рівні.

Державне стимулювання інвестицій у промисловість країни активно використовується урядом США і передбачає, насамперед, 
широке інформування бізнес-середовища про наявні і потенційні інвестиційні можливості та комплекс заходів в сфері забезпечення інвестиційного клімату. Введення прискореної амортизації, застосування різних податкових пільг, зменшення ефективної ставки корпоративного податку у США - приклад того, як інструменти фіскальної політики підвищують віддачу від промисловості, продукція якої у зовнішній торгівлі країни відіграє лідируючу роль.

В ролі «держави-підприємця» США беруть на себе основні ризики i відіграють провідну роль у формуванні ринків в рамках розробки та комерціалізації нових технологій, які вважаються важливими для країни. Шляхом фінансування вкрай ризикованих досліджень «держава-підприємець» знижує ризик для приватних інвесторів і тим самим відіграє незамінну роль каталізатора істотних інновацій. Таким чином, в США держава виступає головним джерелом фінансування на ранніх етапах інноваційної діяльності; при цьому на державний сектор припадає понад 50\% витрат на фундаментальні дослідження, а на приватний сектор менше 20\% [20]. Такі державні інвестиції поширюються на різні види досліджень, більшість 3 яких має вкрай невизначеним потенціалом з точки зору майбутньої віддачі. Це, де-факто суперечить ліберальним лозунгам та підходам Вашингтонсього консенсусу для країн, що трансформуються.

В ролі «держсави-координатора» США створюють мережі міэс різними суб'єктами в інноваційних системах (наприклад, компаніями, фінансовими установами, науково-дослідними інститутами $i$ державними фондами), а також в рамках організацій і установ та управляють цими мережами. Таким чином, вони спонукають різного роду фірми вбудовуватися в децентралізовану інноваційну систему, що охоплює галузевий, регіональний і національний рівні. 3 урахуванням такого своєрідного мережевого характеру промислової політики і пов'язаної з ним відсутності єдиної установи, яка відповідала б за цю політику, такого роду державні заходи з проведення промислової політики іноді називають діями «держави прихованого розвитку».

Наступ Великої рецесії та прихід президента Д. Трампа ознаменував прийняття цілого ряду більш помітних заходів загальної політики, спрямованих на досягнення спільної мети відродження американського промислового виробництва. Водночас, ці заходи, як правило, не вважають частиною промислової політики, оскільки їх безпосередня мета полягає 
в недопущенні масових банкрутств і широкомасштабного безробіття. Попри це більшість із запроваджуваних заходів нової індустріалізації орієнтовані на внутрішнє промислове виробництво США через його найважливіше значення для технологічних інновацій, зростання експорту та створення добре оплачуваних робочих місць в США, завдяки чому сектор промислового виробництва знову стає ключовим компонентом конкурентоспроможної та інноваційної економіки.

Багато із досвіду США країни ЦСЄ застосовували для стимулювання малого та середнього бізнесу. Світовий досвід свідчить про те, що малий бізнес, до якого у більшості країн входить також і середній бізнес (МСБ), є ключовим сегментом сучасної ринкової економіки, в якому зосереджена значна частина національних економічних ресурсів. Так, більше 95\% від загальної кількості підприємств США припадає на МСБ, саме малі та середні підприємства виробляють майже половину обсягу сукупного випуску продукції, створюють більш 75\% нових робочих місць [23].

Доречно в цьому контексті пригадати і те, що у США майже кожна серйозна компанія - світовий чемпіон-єдиноріг із ринковою капіталізацією більше 1 млрд. дол. США - спочатку була створена як підприємство малого бізнесу. Таким чином, мале підприємництво у США і інших економічно розвинених країнах є основою ринкової інфраструктури.

Згідно із визначенням Адміністрації малого бізнесу США (Small Business Administration - $\boldsymbol{S B} \boldsymbol{A}$ ), компанія відноситься до малого бізнесу, якщо в ній працює менше 500 співробітників. На сьогоднішній день в США створено близько 27 млн. компаній малого бізнесу. Щорічно у США створюється близько 600 тисяч підприємств малого бізнесу і зникає близько 500 тисяч. Зважаючи на це, особливе значення для розвитку малого бізнесу в США відіграє відповідна державна підтримка. Зокрема через Програму SBIR (Small Business Innovation Research) [31] - кожне федеральне відомство США виділяє малим високотехнологічним підприємствам гранти на участь у програмах НДДКР цих відомств. Субсидії від держави одержали понад 33 тис. фірм на першому етапі і 12 тис. на другому, на загальну суму 7,7 млрд. дол. США.

Основні принципи державної допомоги малому підприємництву були закладені ще за часів Великої депресії, після якої надавалися субсидії малим і середнім підприємствам, оскільки саме малий бізнес за тих часів 
створював основні робочі місця в країні. Законодавчу основу малого підприємництва становить Закон про малий бізнес, прийнятий в 1953 році, який визначив пріоритетну значимість державних інтересів в допомозі та підтримці малого бізнесу з ціллю сприяння зайнятості населення.

У тому ж році у США було створено спеціалізовану Адміністрацію SBA, місія якої полягає у відстоюванні та захисті інтересів малого бізнесу на урядовому рівні. Дана організація надає консультаційну, фінансову підтримку, а також допомагає малим підприємствам отримувати державні замовлення і укладати контракти з великими компаніями. Основними завданнями SBA є: сприяння в отриманні кредиту, субсидування і кредитування малого і середнього підприємництва за рахунок власних коштів, надання технічної та інформаційної допомоги бізнесу.

Загалом, американська модель фінансово-кредитної підтримки малого бізнесу передбачає не лише безпосередню підтримку малого бізнесу за рахунок державних коштів, а і незалежне функціонування приватного фінансування малого бізнесу.

Так, у сфері підтримки МСБ найбільшого поширення у США набули:

- приватні вкладення, як правило, заможних сімей, з метою «агресивного інвестування» частини сімейних коштів у малі підприємства;

- професійні фонди, що розпоряджаються грошима різних організацій;

- ресурси інвестиційних компаній, об'єднань інвесторів для пошуку найбільш привабливих венчурних підприємств;

- ресурси страхових компаній, які зазвичай більш консервативні і часто вимагають певної частки акціонерного капіталу для гарантії своїх інтересів.

Адміністрація малого бізнесу США - SBA - це найбільш важливий i успішно функціонуючий інститут фінансової підтримки малого бізнесу в світі. Щорічно SBA надає більше 60 тисяч кредитних гарантій на суму близько 10 млрд дол. США. У вигляді гарантій здійснюється близько 90\% усього обсягу кредитної допомоги. У якості плати за надання гарантій SBA стягує з комерційного банку або його позичальника лише $1 \%$ від суми позики [29], можна вважати досить вигідним для позичальника. SBA веде досить агресивну політику з метою знаходження ринкових можливостей для малих підприємств, які мають експортний потенціал. Працюючи з різними державними відомствами та університетами, SBA регулює роботу близько 900 центрів розвитку малого бізнесу, які нада- 
ють технічну та управлінську допомогу підприємцям. Безпосереднім результатом діяльності SBA є розширення доступу малих підприємств до кредитного фінансування; зниження ризику приватного позикового капіталу; збільшення частки малого бізнесу в ВВП США. Діючі програми в рамках SBA щорічно оновлюються, а також створюються нові напрямки підтримки малого бізнесу. Найбільш відомими програмами $\epsilon$ три: - 7a; - CDC / 504; - microcredit loans.

У загальному вигляді діяльність SBA з точки зору комерційних банків, що звертаються за гарантією при кредитуванні того чи іншого малого підприємства, можна представити у вигляді узагальненої схеми рис. 1:

За програмою $7 \boldsymbol{a}$ мале підприємство може отримати гарантії, якщо 3 певних причин не здатне запропонувати банку заставу. Так, для суми не більше 750 тис. дол. США гарантія надається у межах 75\% позики, на 100 тис. дол. США - у межах 80\%. Терміни надання гарантії - до 10 років на оборотний капітал і до 25 років на основний, при цьому процентна ставка не повинна перевищувати 2,75\% [27].

Мета програми «504» - допомога в розширенні і модернізації вже діючих малих підприємств. За програмою CDC/504 надається довгостроковий кредит с фіксованою ставкою на купівлю землі, будівель, благоустрій вулиць, ремонт, придбання машин і обладнання. За даною програмою бізнес кваліфікується як малий, якщо його власний капітал не перевищує 7,5 млн дол. США, а середній чистий дохід не вище 2,5 млн дол. США. Гарантія надається в залежності від виду кредиту і складає 40-100\% позики, максимальна її сума варіюється від 1 до 4 млн дол. США [27].

В узагальненому вигляді особливості програм кредитування SBA та види доступних для МСБ кредитів представлені в табл. 1.

Особливу роль у діяльності SBA займає фінансування інноваційних проектів малого бізнесу. У 1981 році було прийнято Закон про інноваційні дослідженнях малого бізнесу (Small Business Innovation Research Act), що посилив вплив держави на інноваційні процеси в країні за рахунок надання малим підприємствам безоплатних субсидій на інноваційну діяльність[18, С. 102]. На урядові міністерства та відомства США покладено обов'язок щорічного виділення частини власних коштів на підтримку малого інноваційного бізнесу. Важливою умовою при наданні цих коштів є відсутність банківського або венчурного капіталу у фінансуванні інноваційної діяльності підпри- 


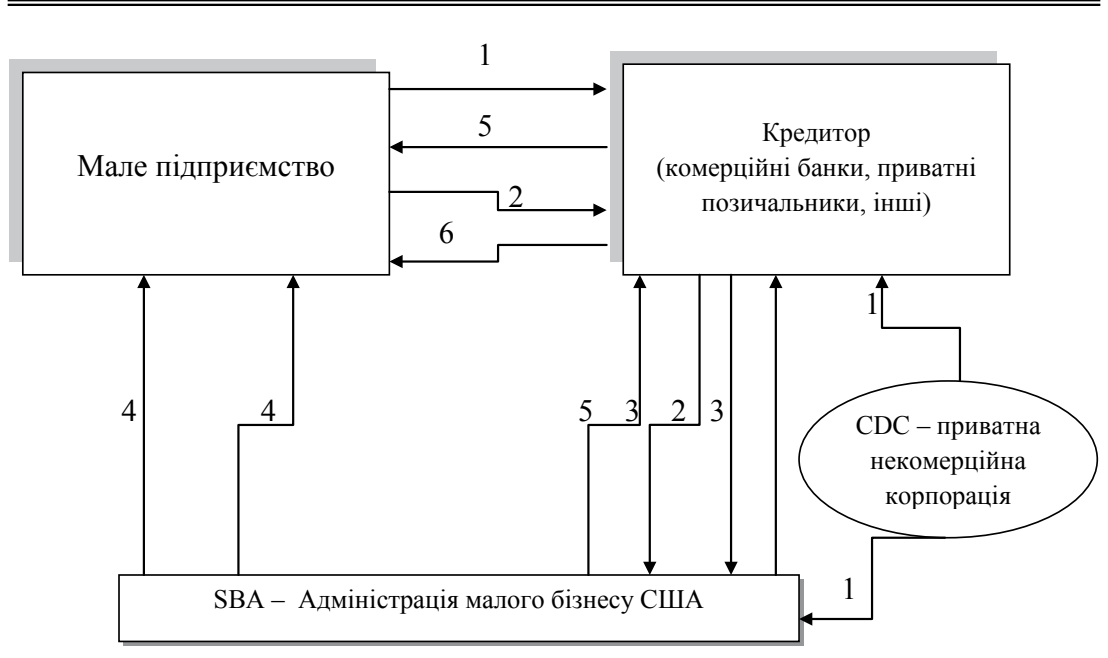

\section{Рис. 1. Схеми кредитування МСБ у США}

Схема кредитування малого бізнесу 7а в США (стрілки прямі):

1 - мале підприємство надає кредитору документи на отримання кредиту;

2 - кредитор вносить заявку на розгляд SBA;

3,4 - якщо згоду на кредитування отримано, то SBA виступає гарантом по кредиту для малого підприємства і одночасно страхує кредитний ризик;

5 - кредитор надає кошти малому підприємству.

Схема кредитування малого бізнесу за програмою CDC/504 (стрілки зигзагоподібні):

1 - приватна некомерційна корпорація (CDC) знаходить кредитора, виконуючи функції посередника між SBA і приватними кредиторами;

2 - мале підприємство надає документи кредитору на одержання кредиту;

3 - кредитор вносить заявку на розгляд ня SBA;

4, 5 - якщо згоду на кредитування отримано, то SBA виступає гарантом по кредиту для малого підприємства і одночасно страхує кредитний ризик;

6 - кредитор надає кредитні ресурси малому підприємству. Джерело: [27, переклад з англ. автора]

ємств. SBA координує різні програми фінансової підтримки інновацій у розвитку малого бізнесу, зокрема, Інноваційні дослідження малого бізнесу (ІДМБ - Small Business Innovation Research) та Передача технологій малого бізнесу (ПТМБ - Small Business Technology Transfer). 
Таблиця 1

Програми SBA i їх особливості

\begin{tabular}{|c|c|c|}
\hline Програма & $\begin{array}{c}\text { Види кредитів в } \\
\text { рамках програми }\end{array}$ & Коротка характеристика \\
\hline \multirow{4}{*}{$7 \mathbf{a}$} & \multicolumn{2}{|c|}{$\begin{array}{l}\text { Спеціальна програма кредитування малого підприємництва, } \\
\text { що включає фінансову допомогу для підприсмств, які мають } \\
\text { особливі вимоги }\end{array}$} \\
\hline & $\begin{array}{l}\text { Експрес SBA i } \\
\text { пілотні програми }\end{array}$ & $\begin{array}{l}\text { Пропонують вдосконалений і прискорений } \\
\text { варіант процедури кредитування для окремих } \\
\text { груп позичальників (для військовослужбовиів, } \\
\text { ветеранів, інших подібних позичальників) }\end{array}$ \\
\hline & $\begin{array}{l}\text { Кредитні } \\
\text { програми розвитку } \\
\text { експорту }\end{array}$ & $\begin{array}{l}\text { Надають фінансову допомогу підприємствам } \\
\text { малого бізнесу, які є експортерами, включають } \\
\text { кредитні програми, спеціально розроблені для } \\
\text { стимулювання експорту }\end{array}$ \\
\hline & $\begin{array}{l}\text { Сільські бізнес- } \\
\text { кредити }\end{array}$ & $\begin{array}{l}\text { Призначені для надання фінансової підтримки } \\
\text { фермерам. Особливість програми - спрощена } \\
\text { процедура кредитування, оптимізація процесу } \\
\text { оформлення і обробки кредитної заявки }\end{array}$ \\
\hline \multirow{3}{*}{ CDC/ 504} & \multicolumn{2}{|c|}{$\begin{array}{l}\text { Програма надання довгострокового кредитування } 3 \\
\text { фіксованою ставкою для придбання основних фондів. } \\
\text { В рамках програми додатково здійснюється фінансування для } \\
\text { поповнення оборотного капіталу, консолідації, погашення або } \\
\text { рефінансування боргу }\end{array}$} \\
\hline & $\begin{array}{l}\text { Кредит під заставу } \\
\text { від приватного } \\
\text { кредитора }\end{array}$ & $\begin{array}{l}\text { Надання кредиту під забезпечення, яке } \\
\text { покриває до 50\% від вартості проекту }\end{array}$ \\
\hline & $\begin{array}{l}\text { Кредит під заставу } \\
\text { CDC }\end{array}$ & $\begin{array}{l}\text { Вид кредитування за участю CDC, при якому } \\
\text { 100\% від вартості проекту покрито. SВА надає } \\
\text { повну гарантію боргових зобов'язань (100\%) } \\
\text { при забезпеченні заставою, що покриває } \\
\text { до 40\% від вартості проекту. Внесок від } \\
\text { позичальника становить не менше } 10 \% \text { від } \\
\text { вартості проекту }\end{array}$ \\
\hline Microloans & \multicolumn{2}{|c|}{$\begin{array}{l}\text { Програма мікрокредитування надає невеликі короткострокові } \\
\text { кредити малому бізнесу. } \\
\text { Максимальна сума кредиту становить } 50 \text { тис. дол. США (середній } \\
\text { розмір мікрокредиту - } 13000 \text { дол. США) }\end{array}$} \\
\hline
\end{tabular}

Джерело: SBA USA [25] 
За програмою ІДМБ на конкурсній основі здійснюється фінансування підприємств малого бізнесу, що займаються розробками нових продуктів і технологій, шляхом укладення з ними контрактів на видачу грантів. У 2010 році дослідницький фонд, кошти з якого використовуються для контрактів і грантів, перевищив 1 млрд дол. США. Більше половини грантів отримали фірми з менше ніж 25 працівниками і третина грантів отримали фірми 3 менше ніж 10 працівниками.

Програма ІДМБ складається з двох етапів:

- початковий етап (надається до 150 тис. дол. США на технологічне обгрунтування проекту);

- заключний етап (надається до 1 млн. дол. США на створення прототипу технології протягом 2 років).

Що стосується програми ПТМБ, то згідно неї надається фінансове сприяння малим підприємствам, які працюють за підтримки неприбуткових науково-дослідних організацій. Причому наукова організація повинна внести свій вклад не менше 30\%, а підприємство - не менше $40 \%$ загального обсягу необхідного фінансування. Так, у 2010 році фонд програми ПТМБ склав понад 100 млн. дол. США [25]. Статистика за програмами ІДМБ і ПТМБ у 2003-2012 рр. відображена у табл. 2:

Таблиця 2

Фінансування інноваційного бізнесу у США

\begin{tabular}{|c|c|c|c|}
\hline Рік & $\begin{array}{c}\text { Кількість } \\
\text { переможців } \\
\text { на фінансування }\end{array}$ & $\begin{array}{c}\text { Коефіціснт } \\
\text { ефективності }\end{array}$ & $\begin{array}{c}\text { Загальний обсяг } \\
\text { інвестицій, } \\
\text { млн дол. США }\end{array}$ \\
\hline 2003 & 1488 & $26,8 \%$ & 327.7 \\
\hline 2004 & 1596 & $23,5 \%$ & 369.8 \\
\hline 2005 & 1307 & $21,3 \%$ & 329.3 \\
\hline 2006 & 1269 & $23,1 \%$ & 351.6 \\
\hline 2007 & 1142 & $24,5 \%$ & 304.5 \\
\hline 2008 & 1242 & $28,5 \%$ & 341.1 \\
\hline 2009 & 1108 & $24,5 \%$ & 339.6 \\
\hline 2010 & 1079 & $17,0 \%$ & 334.4 \\
\hline 2011 & 902 & $14,1 \%$ & 311.1 \\
\hline 2012 & 1095 & $18,7 \%$ & 366.8 \\
\hline
\end{tabular}

Джерело: SBA USA [25] 
Із даних таблиці видно, що коливалися та дещо зменшувалися у посткризовий період після 2008 року із року в рік такі показники:

- кількість заявок, що перемогли у конкурсі на отримання гранту за програмами ІДМБ і ПТМБ;

- загальний обсяг інвестицій, який лише у 2012 році показав незначне зростання;

- коефіцієнт ефективності (success rate), що дорівнює процентному відношенню ефективності, до усіх поданих заявок.

Таким чином, можна зробити висновок про поступове посилення вимог до якості та перспективності майбутніх проектів малого бізнесу.

Ще одним напрямком діяльності SBA є сприяння експорту, в тому числі товарів (послуг) підприємств малого бізнесу. У зв’язку з цим спільно з Міністерством торгівлі США створені Центри сприяння розвитку експорту.

Інший напрямок діяльності SBA - інформаційна підтримка та навчання підприємців. Особливу значущість представляють центри жінок-підприємців Woman Business Centers (WBCs). Фінансування даної організації здійснюється урядом США з метою підтримання гендерної рівності.

Досить великим інститутом підтримки малого бізнесу у США $\epsilon$ Association of America's Small Business Development Centers $(\boldsymbol{A S B D C})$. В рамках ASBDC по всій країні функціонують міжрегіональні підрозділи і близько 1000 місцевих центрів (Small Business Development Centers ( $S B D C s)$, які фінансуються урядом США. Такі центри надають комплекс послуг, пов'язаних з конкретними проектами в різних сферах дрібного і малого підприємництва [27].

Таким чином, американська система фінансово-кредитної підтримки малого бізнесу з метою здійснення промислової політики досить ефективно поєднує державні та приватні форми фінансування, і iї досвід дуже корисний і частково використовується для імплементації в країнах ЦВЄ.

\section{4. Досвід Нової промислової політики у країнах регіону ЦСЄ}

У країнах ЄС частка МСП у загальній вартості експорту складала в 2015 р. близько 35\%, а в Україні - 14,5\% [11, с. 41]. Резерви для залучення МСП для виконання цілей нової промислової політики шляхом зростання 
експорту є, але на шляху їх реалізації стоять досить серйозні перешкоди, a саме: «визначення бізнес-можливостей за кордоном; ідентифікація та аналіз ринків; налагодження контактів із закордонними клієнтами; забезпечення надійного представництва комерційних інтересів компанії за кордоном; доступ до фінансування зовнішньоекономічної діяльності; спроможність менеджменту приділити достатньо часу управлінню діяльністю компанії на зовнішніх ринках; залучення професіоналів для допомоги керівництву при здійсненні операцій на зовнішніх ринках: покриття витрат виходу на міжнародні ринки; протидія недобросовісній конкуренції: труднощі в плані отримання державної підтримки» [21].

Одним із стимулюючих засобів нової промислової політики є практика списання боргів країнам, що застосовується переважно у випадках, коли позичальники мають «критичні» або близькі до них рівні кредитних ризиків. Списання боргу перед кредиторами-членами Лондонського клубу вперше було застосовано в 1990р. щодо Мексики, Коста-Ріки та Венесуели. В I половині 90-х рр. мало місце списання від 30 до 50\% комерційних боргів Болгарії, Румунії, Угорщини, Польщі, Сгипту, яке було обумовлене не тільки економічними, а й політичними міркуваннями. Приклад Польщі свідчить, що поряд з успіхами ринкових перетворень при списанні боргів до уваги бралася ії допомога в проведенні операцій в Іраці. До того ж, за окремими оцінками, обсяг заборгованості цих країн оцінювався понад 600\% відносно річного експорту, тобто більше, ніж вдвічі перевищував критичний рівень. Списання боргу застосовується також і в інших випадках, наприклад, при реалізації технології випуску довгострокових Брейді-облігацій різних модифікацій для країн, що потерпають від надмірної заборгованості.

Тривалі тренди зростання економіки Польщі помітно перевищують динаміку інших 27 країн ЄС. Запорукою швидкого розвитку економіки країни $є$ підвищення продуктивності праці, підвищення ефективності виробництва завдяки впровадженню нових технологій та інвестиціям. Значною мірою такі досягнення стали наслідком реалізації списання боргів та започаткування заходів промислової політики. Це добре описав головний творець польського економічного дива Гж. Колодко [6, с. 65], дійшовши до висновку, що «країни які вміють робити з відповідних економічних теорій належні висновки для економічної політики, розвиваються швидше... $\mathcal{C}$ шанси утриматися на 
шляху швидкого зростання протягом багатьох років, як для Польщі у період 1994-1997 рр., коли ВВП на душу населення зріс на цілих 28\%».

У 1989 р. польський уряд почав переговори на тему часткової погашення боргу країни. В першу чергу, вони були проведені з 17 державними кредиторами, яких представляв Паризький Клуб. Закінчилися переговори у 1991 р. підписанням протоколу про 50\%-й редукцію і 50\%-й реорганізацію зовнішньої заборгованості по прийнятих довго- i середньострокових кредитах.

Погашення мало умовний характер (полягало в редукції зобов'язань в два етапи спочатку 30\% у 1991-1994 рр., а наступні 20\% у 1994 р., але тільки при виконанні Польщею наступних умов: своєчасної сплати 20\% від відсотків в 1991-1994 рр.; проведення економічних реформ під контролем МВФ; встановлення в прочесі переговорів 3 приватними кредиторами такого ж за масштабом погашення боргу.

Реорганізація полягала в реструктуризації зобов'язань до 2008 р. (відносно 16 держав) і до 2014 р. (тільки відносно Японії). Графік виплат був погоджений з наявними платіжними можливостями Польщі. Державні кредитори погодилися також на так звану екоконверсію, тобто переказ до 10\%, але не менше 20 млн дол., належних їм в якості внесків і відсотків, на рахунок Екофонду. Ці засоби призначалися для фінансування витрат, пов'язаних з охороною довкілля в Польщі. Переговори з приватними кредиторами (а це більше 470 комерційних банків) були «набагато важчими, попри те, що зобов'язання Польщі тут складали менш 1/5 загального боргу, тоді як відносно урядів інших держав - близько 2/3» [7, с. 83].

Переговори з Лондонським Клубом, який представляє приватних кредиторів, закінчилися в 1994 р. 3 належних їм близько 14 млрд дол. Польщі дозволили викупити близько 1/ 4 за готівку за ціною 41 цент за основний борг по поновлюваних кредитах 70-х років і за ціною 38 центів - за борг по поновлюваних кредитах 80-го року. Додатково початкова квота була зменшена більш ніж на $20 \%$ в результаті погашення. Частину зобов'язань (близько 54\%), що залишилася, приватні банки замінили на випущені Польщею в звернення так звані облігації Brady, які польська сторона зобов'язалася викупити до 2014 і 2024 pp. Це означає, що цю частину боргу Польща досі не обслуговує, а його сплата буде зроблена під час викупу облігацій Брейді, деноминіновані 
переважно в доларах. Основна ідея таких облігацій полягає в конвертації державного боргу в особливі цінні папери, забезпечені безкупонними казначейськими облігаціями США строком до 30 років.

У промисловій політиці Польщі еволюційно змінювались підходи від переважно вертикальних до горизонтальних. За даними Європейської комісії, сьогодні заходи горизонтальної підтримки становлять понад 70\% від загального обсягу державної допомоги в Польщі. Внесок МСП у ВВП Польщі перевищує $51 \%$, а частка у загальній зайнятості - 68\% [4, с. 56]. Основні пріоритети горизонтальної промислової політики передбачають ринкові умови, стабільне і передбачуване законодавство, доступність фінансових, трудових, інноваційних ресурсів. Ключовими передумовами успіху промислової політики Польщі дослідники, зокрема І. Гужва [3, с. 102] виділяють стимулювання промислового експорту. У рамках урядової програми підтримки експорту з Республіки Польща підприємства-експортери можуть залучати кредитні ресурси на довгостроковій основі під страхове покриття польської Експортно-страхової агенції «Корпорація страхування експортних кредитів» (Export Credit Insurance Corporation Joint Stock Company $(\boldsymbol{K} \boldsymbol{U} \boldsymbol{K} \boldsymbol{E})$. Кошти залучаються для фінансування постачання продукції польських виробників на експорт.

Існує підтримка інвестицій у провідні галузі за різними категоріями (нові інвестиції, прямі іноземні інвестиції, створення нових робочих місць тощо). Як інструменти сприяння інвестиціям використовуються спеціальні інвестиційні режими, урядові гранти за Програмою підтримки інвестицій (що мають важливе значення для економіки на 2011-2020рр.), ресурси структурних фондів ЄС тощо. За рівнем інвестиційної конкурентоспроможності Польща займає високі місця у СС. Підтримка створення нових робочих місць «залежить від проекту та може сягати 15,6 тис. злотих (4 тис. дол. США) за одне робоче місце. Також існує підтримка навчальних програм, спрямованих на підвищення кваліфікації персоналу - максимальна сума компенсації 70\%» [2, с. 44];

Пільгові інвестиційні режими в Польщі діють на території 14 спеціальних економічних зон (СЕ3). Сприятливі умови ведення господарської діяльності на цих територіях передбачають податкові пільги, полегшені процедури працевлаштування, якісне інфраструктурне забезпечення. Виробники в індустріальних парках, розташованих в 
польських СЕЗ, можуть отримати від держави звільнення від сплати корпоративного податку або податку на доходи фізичних осіб, а також часткове звільнення від податку на майно.

Фінансове сприяння інноваційно-технологічному поступу економіки відбувається у рамках програми інтелектуального розвитку («Kredyt na innowacje technologiczne», Programu Inteligentny Rozwój), одночасно за вищеописаним досвідом США забезпечується полегшений доступ до фінансових ресурсів для малих і середніх підприємств (MCI) у формі грантів і кредитів, які фінансуються з коштів державного бюджету та європейських фондів. Стимулювання розвитку МСП, особливо в інноваційних галузях, які виготовляють продукцію з високою доданою вартістю для уряду є пріоритетним. Важливою також $є$ підтримка промислового розвитку регіонів як складової розвитку країни в рамках успішної реформи децентралізації.

Стабільність та висока активність фінансового сектора у пропозиції послуг для підприємств також є ключовим фактором нової промислової політики. Варшавська фондова біржа $є$ найбільшим фінансовим ринком у регіоні ЦСЄ і $є$ дійсно інноваційним хабом для торгівлі фінансовими інструментами, відкритим для емітентів та інвесторів 3 Польщі та інших країн.

За останні 15 років Угорщина досягла високих темпів економічного зростання, випередивши за ними в середньому Свропейський Союз, завдяки своїй спроможності залучати прямі іноземні інвестиції та наявності власної валютної політики - невходження до зони євро та гнучкості курсу власної національної валюти - форінту. Угорщині стала лідером регіону ЦВС у залученні іноземних інвестицій шляхом заснування індустріальних парків. Світовий досвід переконує, що індустріальні парки можуть бути ефективним способом залучення інвестицій у певні галузі економіки, сприяти зменшенню безробіття й розвитку кращих технологій та інфраструктури.

Упродовж останніх десяти років Угорщині вдалося стати лідером у залученні іноземних інвестицій шляхом заснування промислових парків. Завдяки своїй спроможності залучати прямі іноземні інвестиції в наукомісткі сфери Угорщина також досягла найбільших успіхів в електронній промисловості, на відміну від сусідньої Словаччини, де було зроблено пріоритет на розвиток машинобудування, насамперед, тран- 
спортного. Прямі іноземні інвестиції необхідні Угорщині для інтеграції наявних і майбутніх компаній у сфері виробництва електроніки до глобальних виробничих мереж. Тимчасом як 90\% прямих іноземних інвестицій до країни спрямовуються до електронної промисловості, 2001 року обсяги угорського експорту становили 50\% усього обсягу експорту електронних товарів з країн Центральної та Східної Свропи.

Індустріальні парки в Угорщині вперше засновано ще далекого 1997 року з ініціативи центральної влади. Спочатку ці парки були розташовані в західній Угорщині. До них вдалося залучити великі міжнародні компанії, що виробляють продукцію, орієнтовану на експорт. Ці парки виявилися дуже ефективними, вони швидко розвивалися й досягли вагомих результатів. Починаючи з 1997 року, численні органи місцевого самоуправління очолили процес розвитку промислових парків шляхом запровадження економічних програм регіонального розвитку. Більшість компаній у другій групі парків становили вже малі та середні підприємства, що виробляють продукцію, орієнтовану не на експорт, а на внутрішній ринок.

На сьогодні в Угорщині налічується більш як 160 різноманітних індустріальних парків, серед яких інвестори можуть обирати відповідно до їхніх видів діяльності та вимог до спеціалізації. Кількість індустріальних парків в Угорщині та їхні показники ефективності (прибутковість та обсяги експорту) зросли більше як уп'ятеро проти 1997 року, тимчасом як кількість людей, які працюють у промислових парках, збільшилася майже вчетверо. Угорська агенція інвестицій i розвитку торгівлі стверджує, що нині індустріальні парки виробляють $25 \%$ загальних обсягів промислового виробництва, а також 40\% промислової продукції, що експортується. Драйвери зростання -у інтенсифікації праці та віддачі від труда. Водночас, продуктивність праці в індустріальних парках, більш як на 70\% вища за середню продуктивність праці в угорській економіці й лише на 15\% нижча за середню продуктивність праці загалом в СС.

В Угорщині індустріальні парки пропонують наявним і потенційним інвесторам сприятливі умови діяльності, включаючи підтримку органів місцевого самоуправління та досить різноманітні пільги. Зараз парки пропонують широкий асортимент економічних стимулів, таких як податкові знижки та пільги для розвитку науково-дослідної роботи. 
Усі індустріальні парки в Угорщині пропонують такі послуги:

- Базова інфраструктура. Вона містить послуги водопостачання та водовідведення, постачання електроенергії, газу, заасфальтовані дороги, мережу телефонного зв'язку та освітлення території. Розвиненіші промислові парки пропонують додаткову інфраструктуру, наприклад, доступ до Інтернету, цифрові мережі зв'язку з комплексними послугами, асиметричні цифрові абонентські лінії, доступ до волоконно-оптичних ліній зв'язку (ВОЛЗ) та ін.

- Допоміжні послуги - адміністративні та інноваційні послуги. Адміністративні послуги включають пункт «єдиного вікна», філії банків, адміністрацію, управління та юридичне представництво компаній. Додаткові інноваційні послуги: консалтинг та моніторингу проведення тендерів.

- База постачальників. Індустріальні парки призначені для підтримки розвитку потужної бази постачальників.

- Професійна співпраця. Індустріальні парки можуть допомогти знизити виробничі витрати шляхом налагодження співпраці між схожими технічними робочими операціями/компаніями.

Окрім надання цих послуг, Угорщина також має відмінну транспортну систему. Більшість індустріальних парків мають автомагістралі, поєднані з європейською мережею автомобільних шляхів. Водночас навіть до найвіддаленіших регіонів можна дістатися завдяки 60 аеропортам у достатньо малій за площею Угорщині.

За державної підтримки в угорських індустріальних парках почали приділяти більше уваги науково-дослідній роботі. Окрім цього, в Угорщині існує низка навчальних закладів, що забезпечують компанії високоосвіченими та інтелектуальними кадрами.

Уряд Угорщини бере активну участь у розвитку індустріальних парків і на місцевому, і на національному рівні. На місцевому рівні запровадження економічних програм регіонального розвитку дало змогу органам місцевого самоврядування ініціювати розвиток індустріальних парків, сприяє активному пошуку потенційних інвесторів. Окрім цього, хоча й попередні засоби заохочення (такі як податкові пільги або цільові субсидії) вже унеможливлено внаслідок вступу Угорщини до $\mathrm{CC}$, органи місцевого самоврядування мають повноваження зменшувати загальну ставку промислового податку. 
На національному рівні уряд Угорщини пропонує стимули та фінансову допомогу для сприяння розвитку промислових парків і залучення інвесторів. Після того, як інвестори отримали право називатися «резидентів індустріальних парків», вони можуть подавати заяви на різноманітні види фінансової підтримки: від коштів національних субсидій до безмитних зон. Уряд Угорщини також пропонує забезпечення спільного фінансування різноманітних видів інвестицій. Інвестори можуть також отримати фінансову допомогу шляхом надання заяви на отримання грантів до СС.

Гранти СС концентрують увагу на створенні нових робочих місць, розвитку довкілля та інфраструктури, інвестуванні до сільськогосподарського сектору, навчанні та перепідготовці робочої сили і підтримці інноваційного розвитку. Індустріальні парки в Угорщині є засобом забезпечення подальшого економічного розвитку, зокрема для створення нових робочих місць, поліпшення технологій і зменшення неоднаковості розвитку регіонів. Хоча інвестиції поліпшили загальний стан економіки країни, Уряд Угорщини визнає, що в усій країні інвестиції розподіляються нерівномірно, і географічні відмінності все ще наявні.

Як показали Оніщенко та Гужва, особливістю угорської промислової політики є те, що «національні торгові доми розглядаються як один з трьох ключових елементів системи підтримки зовнішньоекономічної діяльності країни поряд з Угорським агентством зі сприяння інвестиціям та національним Ексімбанком» [11, с. 43].

Для реалізації державної підтримки експорту уряд Угорщини разом з угорською Торгово-промисловою палатою (ТПП) у 2013 р. заснував AT «Угорський національний торговий дім», який вже у перший рік своєї роботи 2014 р. відкрив свої представництва у 25 країнах світу і посприяв експорту 2,3 тис. малих і середніх підприємств країни на загальну суму 125 млн. Євро [22].

Важливість функціонування торгових домів в Угорщині полягає у виконанні ними подвійної ролі у просуванні експорту: з одного боку вони являють собою співтовариства, які об'єднують професіоналів у сфері міжнародної торгівлі для допомоги бізнесу, а з іншого - виступають у ролі посередника між владою та бізнесом з питань підтримки зовнішньоекономічної діяльності, що буде цікавим механізмом і для промислової політики України. 
Чехія також однією із перших в ЦВС у 1998 р. запровадила державну програму розвитку індустріальних парків. Протягом 7 років після запуску було створено близько сотні індустріальних парків, інвестори вклали в нові виробництва понад 9 млрд євро, створили більше 70 тис. робочих місць. В. Галасюк показує, що «у 1990 р. за реальним ВВП на душу населення Чехія випереджала Україну у 2 рази, сьогодні вона випереджає Україну за цим показником уже в 4 рази» [2, с. 44]. У Чехії виробники в індустріальних парках за різними програмами можуть отримати звільнення від сплати корпоративного податку на строк до 10 років та на звільнення від податку на майно 5 років. Крім того, Чеська республіка надає гранти до 300 тис. крон (12 тис. дол. США) за створення кожного нового робочого місця в індустріальних парках.

\section{5. Висновки та рекомендації}

Основою успішного стимулювання зростання промисловості в регіоні виступили: наявність власної валюти (злотого, крони та форинта) і проведення незалежної валютно-курсової політики, створення індустріальних парків і спеціальних економічних зон, а також застосування механізмів здешевлення і страхування експорту за допомогою Експортно-кредитних агентств.

Особливістю Польщі в проведенні промислової політики на новій основі було списання більшої частини і успішна реструктуризація об'єму державного боргу, що залишився. На вигідних для Польщі умовах такий борг був перепрофільований на довгий строк як перед міжнародними фінансовими організаціями (МВФ, Світовий банк тощо), так і перед великими приватними кредиторами. Зменшення боргового тягаря заклало основу для створення нових робочих місць і технологічного переозброєння в промисловості.

Особливістю нової промислової політики Угорщини є державні заходи по підтримці підприємств із спеціалізацією на нових технологіях з великою часткою додаткової вартості - зокрема електроніки, на відміну від сусідньої Словаччини, де Урядом був узятий курс на стимулювання створення кластера автомобілебудування, що вирішувало проблему безробіття та зменшення трудової міграції. Також особливістю Угорщини є розвинена система торгових домів з метою просування угорського експорту за рубіж при фінансовому сприянні держав- 
ного Експортно-імпортного банку і Експортно-кредитного агентства, працюючих в тісній взаємодії.

Рекомендуємо в рамках проведення нової промислової політики в Україні активно залучати до експортної діяльності малі та середні підприємства (МСП) та стимулювати їх роботу шляхом створення спеціалізованого державного Агентства розвитку малого та середнього бізнесу за прикладом Сполучених Штатів Америки та з використанням досвіду країн ЦВС.

Використовуючи досвід Угорщини, в Україні пропонуємо створення Урядом Національного торгового дому з мережею представництв у крупних регіонах для фінансової та організаційної підтримки просування експорту у взаємодії з державним спеціалізованим Укрексімбанком та новоствореним Експортно-кредитним Агентством України [19]. Також ми розглядаємо наявну потребу вітчизняної промисловості у використанні польського та чеського досвіду щодо створення та податкового стимулювання урядом та місцевими Об'єднаними територіальними громадами (ОТГ) в Україні розгалуженої мережі індустріальних парків в рамках процесів децентралізації.

\section{Список літератури:}

1. Вайцзеккер Е.У. фон, Війкман А. Сome On! Капіталізм, недалекоглядність, населення і руйнування планети. Доповідь Римському клубу : пер.з англ. Ю. Сірош; за наук. ред. В. Вовка, В. Бутка. Київ : Саміт-Книга, 2019. 276 с.

2. Галасюк В.В. Індустріальні парки: світовий досвід та перспективи створення в Україні. Економічний аналіз. 2018. Т. 28. № 1. С. 40-50.

3. Гужва І.Ю. Актуалітети зовнішньоторговельної політики України: монографія. Київ : Національна академія управління, 2017. 298 с.

4. Гужва І.Ю. Україна в глобальній торгівлі : монографія. Київ : Зовнішня торгівля, 2015. $236 \mathrm{c.}$

5. Кіссінджер Генрі. Світовий порядок. Роздуми про характер націй в історичному контексті : пер. з англ. Надія Коваль. Київ : Наш формат, 2017. 320 с.

6. Колодко Гжегож В. Глобализация, трансформация, кризис - что дальше? Москва : Магистр, 2012. 176 с.

7. Колодко Гжегож В. Посткоммунистический переход к рынку и демократии: уроки тридцатилетнего польського опыта. Экономическая теория, 2019. № 2. С. 75-98.

8. Корнєєв В.В. Фінансові посередники як інститути розвитку : монографія. Київ : Основа, 2007. 192 с.

9. Макстон Грем, Рандерс Йорген. У пошуках добробуту. Керування економічним розвитком для зменшення безробіття, нерівності та змін клімату. Київ : Пабулум, 2017. 320 с. 
10. Москаленко О.М. Теорія і модель випереджаючого економічного розвитку в системі суспільних стратегічних потреб. Монографія. Київ : КНЕУ, 2014. 550 с.

11. Оніщенко В., Гужва I. Стимулювання національного експорту. Зовнішня торгівля: економіка, фінанси, право. 2017. № 6. С. 33-47.

12. Панченко В. Г. Нова промислова політика України як прояв ліберального економічного патріотизму. Міжнародні відносини. Серія: Економічні науки. 2015. № 6. С. 1-21.

13. Панченко В., Рєзнікова Н. Від протекціонізму до неопротекціонізму: нові виміри ліберального регулювання. Міжнародна економічна політика. 2017. № 2(27). C. 95-117.

14. Райнерт Е.С. Як багаті країни забагатіли... і чому бідні країни лишаються бідними. Київ : Темпора, 2014. 444 с.

15. Резнікова Н.В. Економічна неозалежність країн в умовах глобальних трансформацій. Київ : АграрМедіаГруп, 2018. 460 с.

16. Резнікова Н.В. Політика економічного націоналізму: від витоків до нових варіацій економічного патріотизму. Економіка і держава. 2017. № 8. С. 5-11.

17. Резнікова Н.В. Методологічні засади економічного націоналізму. Економіка і держава. 2017. № 7. С. 4-8.

18. Шульгина И.В. Финансирование малых инновационных предприятий (Опыт США). Науковедение. Москва. 2003. № 2. С. 68-82.

19. Про забезпечення масштабної експансії експорту товарів (робіт, послуг) українського походження шляхом страхування, гарантування та здешевлення кредитування експорту : Закон України від 20.12.2016 р. № 1792-19. URL: http://zakon2.rada.gov.ua/laws/show/1792-19 (дата звернення: 15.09.2019).

20. Aiginger A. Industrial Policy for a sustainable growth path. URL: https://www.oecd.org/eco/Industrial-Policy-for-a-sustainable-growth-path.pdf (дата звернення: 13.08.2019).

21. The Athens Action Plan for Removing Barriers to SME access to international markets. URL: http://www.oecd.org/industry/smes/37818332.pdf (дата звернення: 10.09.2019).

22. European Confederation of International Trading Houses. URL: http://www.citha.eu (дата звернення: 12.09.2019).

23. A. Groth, K. Bhasin. 18 Amazing Facts About Small Businesses In America. Business Insider. 2011. URL: https://www.businessinsider.com/facts-about-smallbusinesses-in-america-2011-8\#70-of-small-businesses-are-owned-and-operatedby-a-single-person-2 (дата звернення: 03.08.2019).

24. Industrial policy for the twenty-first century. UNIDO. 2004. URL: http://www.hks.harvard.edu/fs/drodrik/Research\%20papers/UNIDOSep.pdf (дата звернення: 04.08.2019).

25. NIH Small Business Innovation Research and Small Business Technology Transfer Grants, Fiscal Years 2002-2011. URL: http://report.nih.gov/success_rates/ index.aspx (дата звернення: 22.09.2019).

26. Owen G. Industrial Policy in Europe since the Second World War: What Has Been Learnt? URL: http://www.ecipe.org/app/uploads/2014/12/OCC12012revised.pdf (дата звернення: 07.08.2019). 
27. Small Business Development Center. URL: http://www.americassbdc.org (дата звернення: 11.08.2019).

28. Trade and Development Report, 2014. United Nations. New York. URL: https://unctad.org/en/PublicationsLibrary/tdr2014_en.pdf (дата звернення: 09.09.2019).

29. U.S. Small Business Administration, SBA Programs. URL: http://www.sba. gov (дата звернення: 27.09.2019).

30. US CRADA. URL: https://www.ll.mit.edu/partner-us/small-businessindustry/cooperative-research-and-development-agreements (дата звернення: 16.09.2019).

31. US SBIR. URL: https://www.sbir.gov/news (дата звернення: 25.09.2019).

\section{References:}

1. Waitzekker, E.von, Wijkman A.(2019). Come On! Capitalism, short-sightedness, population and destruction of planet. Lecture to the Club of Rome. Kyiv: Summit-book, 2019. 276 p. (in Ukrainian)

2. Halasiuk, V. (2018). Industrial parkas: world experience and prospects of creation in Ukraine. The Economic analysis, vol. 28, 1, pp. 40-50. (in Ukrainian)

3. Guzhva, I. (2017). Actuality of foreign trade politics in Ukraine: monography. Kyiv: the National academy of management, 298 p. (in Ukrainian)

4. Guzhva, I. (2015). Ukraine in global trade: monography. Kyiv: Foreign trade, 236 p. (in Ukrainian)

5. Kissinger, G. (2017). World order. Reflections are about character of nations in the historical context. Kyiv: Our format, 320 p. (in Ukrainian)

6. Kolodko, G. (2012). Globalization, transformation, crisis - what next? Moscow: Master, 176 p. (in Russian)

7. Kolodko, G. (2019). Post communist passing to the market and democracy: lessons thirty years Polish experience. Economic Theory, no. 2, pp. 75-98. (in Russian)

8. Korneev, V. (2007). Financial mediators as institutes of development: monography. Kyiv : Basis, 192pp. (in Ukrainian)

9. Maxtone, G, Randers, Y. (2017). In Search of Welfare. A management economic development is for reduction of unemployment, inequality and changes of climate. Kyiv : PABULUM, 320 p. (in Ukrainian)

10. Moskalenko, O. (2014). A theory and model of passing ahead economic development are in the system of public strategic necessities : monography. Kyiv: $\mathrm{KNEU}, 550$ p. (in Ukrainian)

11. Onishchenko, V. Guzhva, I. (2017). Stimulation of national export. Foreign trade: economy, finances, right, no. 6, pp. 33-47. (in Ukrainian)

12. Panchenko, V. (2015). New industrial politics of Ukraine as display of liberal economic patriotism. The International relations. Series: Economic sciences, no. 6, pp. 1-21. (in Ukrainian)

13. Panchenko, V., Reznikova, N. (2017). From protectionism to neoprotectionism: new measuring of the liberal adjusting. INTERNATIONAL ECONOMIC POLITICS, 27, pp. 95-117. (in Ukrainian) 
14. Reinert, E. (2014). As rich countries were riched and why poor countries still poor. Kyiv: Tempora, 444 p. (in Ukrainian)

15. Reznikova, N. (2018). Economic neodependence of countries is in the conditions of global transformations. Kyiv: AgrarMediaGrup, 460 p. (in Ukrainian)

16. Reznikova, N. (2017). Politics of economic nationalism: from sources to new variations of economic patriotism. Economy and state, 8 (August), pp. 5-11. (in Ukrainian)

17. Reznikova, N. (2017). Methodological principles of economic nationalism . Economy and state, no. 7, pp. 4-8. (in Ukrainian)

18. Shulgina, I. (2003). Financing of small innovative enterprises (Experience of the USA). Naukovedenie, 2, pp. 68-82. (in Russian)

19. About providing of scale expansion of export of commodities (works, services) of the Ukrainian origin by insurance, guaranteeing and reduction of prices of crediting of export : Law of Ukraine from 20.12.2016 \# 1792-19. URL: http://zakon2.rada.gov.ua/laws/show/1792-19

20. Aiginger A. Industrial Policy for a sustainable growth path. URL: https://www.oecd.org/eco/Industrial-Policy-for-a-sustainable-growth-path.pdf

21. The Athens Action Plan for Removing Barriers to SME access to international markets. URL: http://www.oecd.org/industry/smes/37818332.pdf.

22. European Confederation of International Trading Houses. URL: http://www.citha.eu

23. A. Groth, K. Bhasin (2011). 18 Amazing Facts About Small Businesses In America. Business Insider, 2011. URL: https://www.businessinsider.com/factsabout-small-businesses-in-america-2011-8\#70-of-small-businesses-are-ownedand-operated-by-a-single-person-2

24. Industrial policy for the twenty-first century. UNIDO. 2004. URL: http://www.hks.harvard.edu/fs/drodrik/Research\%20papers/UNIDOSep.pdf

25. NIH Small Business Innovation Research and Small Business Technology Transfer Grants, Fiscal Years 2002-2011. URL: http://report.nih.gov/success_rates/ index.aspx

26. Owen G. Industrial Policy in Europe since the Second World War: What Has Been Learnt? URL: http://www.ecipe.org/app/uploads/2014/12/OCC12012revised.pdf

27. Small Business Development Center. URL: http://www.americassbdc.org

28. Trade and Development Report (2014). United Nations. New York. URL: https://unctad.org/en/PublicationsLibrary/tdr2014_en.pdf

29. U.S. Small Business Administration, SBA Programs, USA. URL: http://www.sba.gov

30. US CRADA. URL: https://www.ll.mit.edu/partner-us/small-business-industry/cooperative-research-and-development-agreements

31. US SBIR. URL: https://www.sbir.gov/news 